\title{
Inhibition of Ligand Binding Ability of Three Porphyrins by an Organic Effector
}

Tomoaki Nishimura, Yoshito Sasaki, Yoshimitsu Tachi, Shuichi Suzuki, Keiji Okada, Masatoshi Kozaki

\begin{tabular}{|c|l|}
\hline Citation & Chemistry - An Asian Journal. 15(5); 594-600 \\
\hline Issue Date & $2020-03-02$ \\
\hline Version of Record & 2020-01-28 \\
\hline Type & Journal Article \\
\hline Textversion & Author \\
\hline $\begin{array}{c}\text { Supporting } \\
\text { Information }\end{array}$ & Supporting information is available at https://doi.org/10.1002/asia.201901711. \\
\hline Rights & $\begin{array}{l}\text { This is the peer reviewed version of the following article: Chemistry - An Asian } \\
\text { Journal Vol.15, Issu.5, p.594-600, which has been published in final form at } \\
\text { https://doi.org/10.1002/asia.201901711. This article may be used for } \\
\text { non-commercial purposes in accordance with Wiley Terms and Conditions for } \\
\text { Use of Self-Archived Versions. }\end{array}$ \\
\hline DOI & \begin{tabular}{c}
$10.1002 / a s i a .201901711$ \\
\hline
\end{tabular}
\end{tabular}

\author{
Self-Archiving by Author(s) \\ Placed on: Osaka City University
}




\title{
Inhibition of Ligand Binding Ability of Three Porphyrins by an Organic Effector
}

\author{
Tomoaki Nishimura, ${ }^{[a]}$ Yoshito Sasaki, ${ }^{[a]}$ Yoshimitsu Tachi, ${ }^{[a]}$ Shuichi Suzuki, ${ }^{[c]}$ Keiji Okada, ${ }^{[a],[b]}$ \\ Masatoshi Kozaki*[a],[b]
}

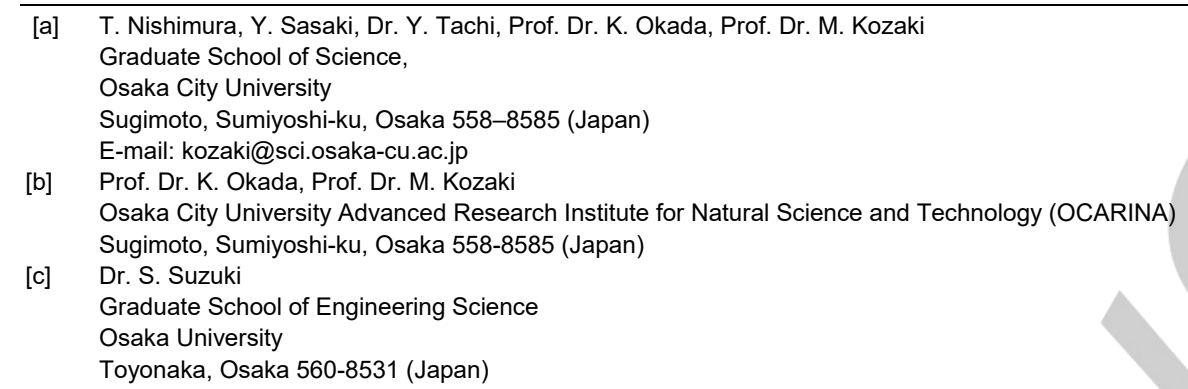

Supporting information for this article is given via a link at the end of the document

\begin{abstract}
A stimulus-responsive receptor 1 was designed and prepared to control the ligand-binding ability of three active sites, two zinc tetraphenylporphyrin units $(\mathrm{P} 1)$ and one zinc diethynyldiphenylporphyrin unit (P2), with one effector molecule 2. Bulky hexarylbenzene units are incorporated as shielding panels in the middle of the flexible side arms of 1 . Spectroscopic titrations indicated that a stable supramolecular complex $\mathbf{1 \cdot 2}\left(K_{1 \cdot 2}=6.7 \times 10^{6}\right.$ $\mathrm{M}^{-1}$ ) was produced via the cooperative formation of multiple hydrogen and coordination bonds. As the result, the binding of a ligand to $\mathrm{P} 1$ was inhibited by $\mathbf{2}$ in a competitive manner. Additionally, the formation of $\mathbf{1 \cdot 2}$ brought about conformational restriction of the side arms to cover both faces of $\mathrm{P} 2$ with the shielding panels. The binding constant of 4-phenylpyridine with $\mathrm{P} 2$ in $\mathbf{1 \cdot 2}$ decreased to $8.9 \%$ of that in 1 . Namely, the ligand-binding ability of P2 was inhibited according to an allosteric mechanism.
\end{abstract}

\section{Introduction}

Some enzymes transform their structures by recognizing chemical stimuli at sites other than the binding sites of ligands, which leads to a change in their ligand-binding activity (allosteric regulation). ${ }^{[1]}$ The allosteric regulation mechanism is a rich source of inspiration for the design of stimulus-responsive receptors and catalysts. ${ }^{[2,3]}$ Metal cations have been popular chemical stimuli in artificial systems because metal complexations generate strong driving force to bring about conformational transformation. ${ }^{[3]}$ In nature, molecular recognition is a common trigger for regulating the activity of active sites in allosteric enzymes. There are, however, a limited number of reports of artificial allosteric systems where molecular recognition brought about the conformational transformation. ${ }^{[4]}$ One reason for this is that it is usually difficult to generate enough driving force to transform the conformation through molecular recognition because it is achieved with weak chemical bond and/or bonding interaction.

In popular artificial allosteric receptors, association of an external chemical stimulus leads to the construction or destruction of preorganized ligand-binding sites to express a positive or negative effect on their activity, respectively. ${ }^{[4]}$ On the other hand, Mirkin et al. applied their weak-link concepts to the development of an allosteric catalyst where accessibility of a substrate to an active site was altered with shielding units. ${ }^{[5]}$ While the shielding strategy is versatile and reliable to switch the activity, a few artificial allosteric systems can be operated by the shielding mechanism.

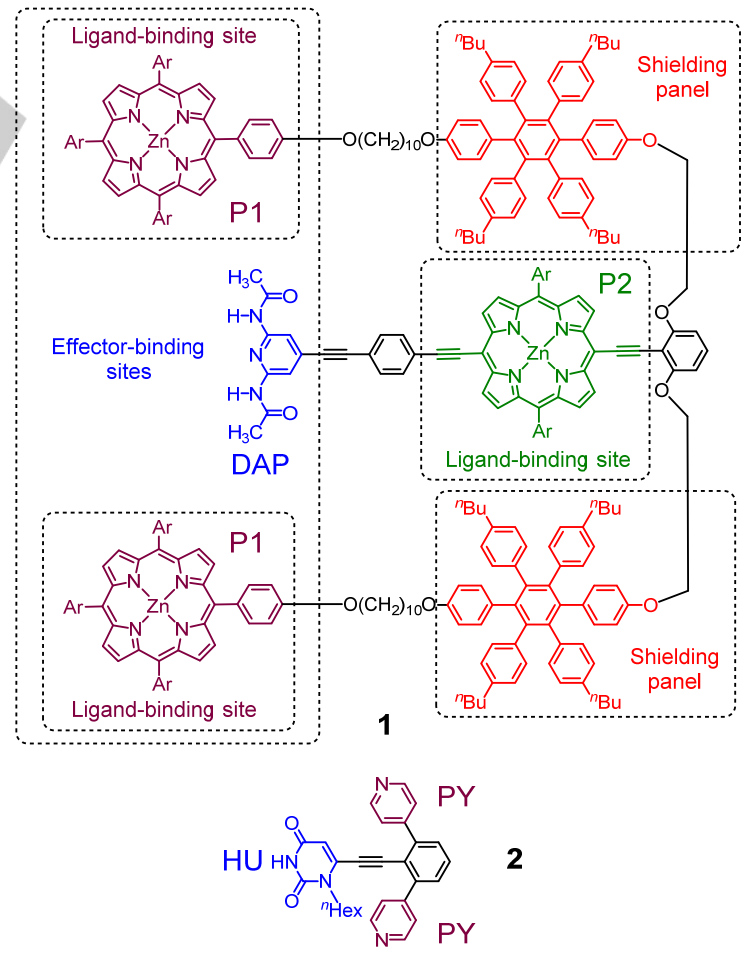

Figure 1. Chemical structures of receptor 1 and effector $2(\mathrm{Ar}=3,5$-di-tertbutylphenyl).

Recently, we reported stimulus-responsive receptor that has a zinc 5,15-diethynyl-10,20-diphenylporphyrin unit (P0) as ligand 
binding sites (Scheme S1). ${ }^{[6]}$ Activity of this sites was suppressed by neutral organic molecule (effector). The binding constant of 4-phenylpyridine with $\mathrm{P0}$, however, reduced only by 0.24 times by the effector. Here, we designed closely related receptor 1 with a pair of sterically bulky shielding panels to enhance the degree of the allosteric inhibition by organic effector 2 (Figure 1). Although the side chains of $\mathbf{1}$ appear to be conformationally flexible, steric bulkiness of the shielding units is probably a dominant factor in the allosteric inhibition. ${ }^{[7]}$ Absorption spectral titrations were performed to see the stability of the $\mathbf{1 : 1}$ supramolecular complex $\mathbf{1 \cdot 2}$ and to evaluate the ability of the ligand-binding sites in both $\mathbf{1}$ and $\mathbf{1 \cdot 2}$. We successfully obtained considerable enhancement in the degree of allosteric inhibition.
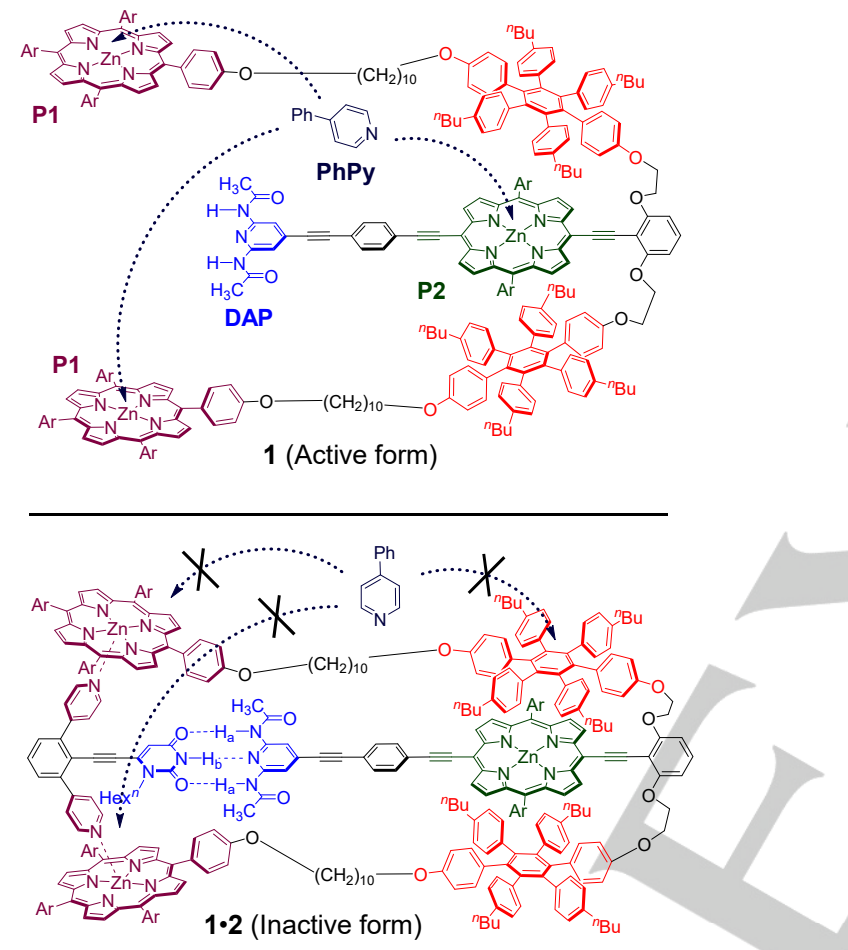

Figure 2. Active and inactive forms of receptor 1

\section{Results and Discussion}

Receptor $\mathbf{1}$ is composed of a linear rigid main rod that has a pair of flexible side arms at one end and a diamidopyridine unit (DAP) at the other end (Figure 1). A sterically bulky shielding panel is incorporated in the middle of each side arm. There are two types of ligand-binding sites in 1: zinc $5,10,15,20$ tetraphenylporphyrin units (P1) at the terminal of each side arm and a zinc 5,15-diethynyl-10,20-diphenylporphyrin unit (P2) at the middle of the main rod. Effector 2 possesses two types of binding units that are a couple of 4-pyridyl (PY) groups and one 1-hexyl-uracil group (HU). It is expected that the ligand-binding ability of 1 is inhibited by 2 according to the following mechanism (Figure 2). The association of $\mathbf{1}$ with $\mathbf{2}$ produces a stable supramolecular complex $\mathbf{1 . 2}$ where both the $\mathrm{P} 1 \mathrm{~s}$ have coordination bonds with PYs, and DAP forms multiple hydrogen bonds with $\mathrm{HU}$. The binding of ligands to P1 is inhibited in a competitive manner thanks to the high stability of $\mathbf{1 \cdot 2}$. In addition, the formation of $\mathbf{1 \cdot 2}$ is accompanied by a large conformational

transformation in the side arms, which results in both the faces of $\mathrm{P} 2$ being covered with the shielding panels. As a result, the ligand-binding ability of P2 is allosterically inhibited.

First, we performed semi-empirical calculations using the PM6 method to check for suitable alkyl chain lengths for the formation of the stable supramolecular complex (Table S2). The results suggested that receptor $\mathbf{1}$ with decamethylene chains $\left(-\left(\mathrm{CH}_{2}\right)_{10^{-}}\right)$between $\mathrm{P} 1$, and the shielding panel is the most suitable for producing the stable supramolecular complex with 2 . The energy-minimized structure of $\mathbf{1 \cdot 2}$ in Figure 3 suggests that the shielding panels reduce accessibility of ligands to P2. These results indicated that 2 can be a good effector for suppressing the ligand-binding ability of 1 .

(a)

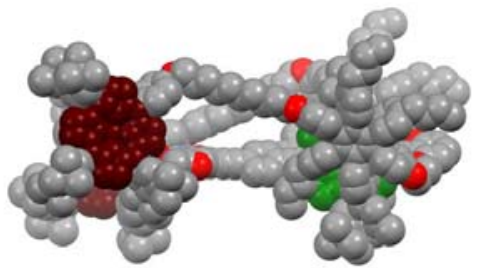

(b)

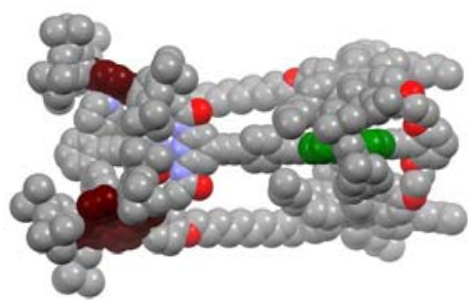

Figure 3. (a) Side and (b) top views of optimized structure of $\mathbf{1 \cdot 2}$ (PM6) Carbon, oxygen, and nitrogen atoms are gray, red, blue, and yellow, respectively. $\mathrm{P} 1$ and $\mathrm{P} 2$ units are purple and green, respectively. All hydrogen atoms are omitted for clarity.
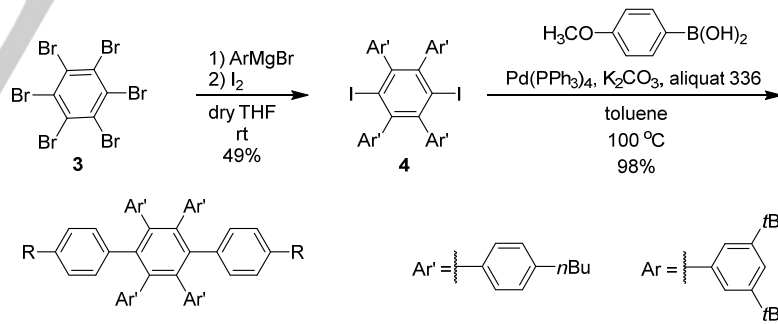
$\begin{array}{lll}\text { 5: } \mathrm{R}=\mathrm{OCH}_{3} & \begin{array}{l}\mathrm{BBr}_{3}, \mathrm{dry}_{\mathrm{CH}_{2} \mathrm{Cl}_{2}} \\ \text { 6: } \mathrm{R}=\mathrm{OH}\end{array} & \begin{array}{l}-20^{\circ} \mathrm{C} \text { to rt } \\ \end{array}\end{array}$
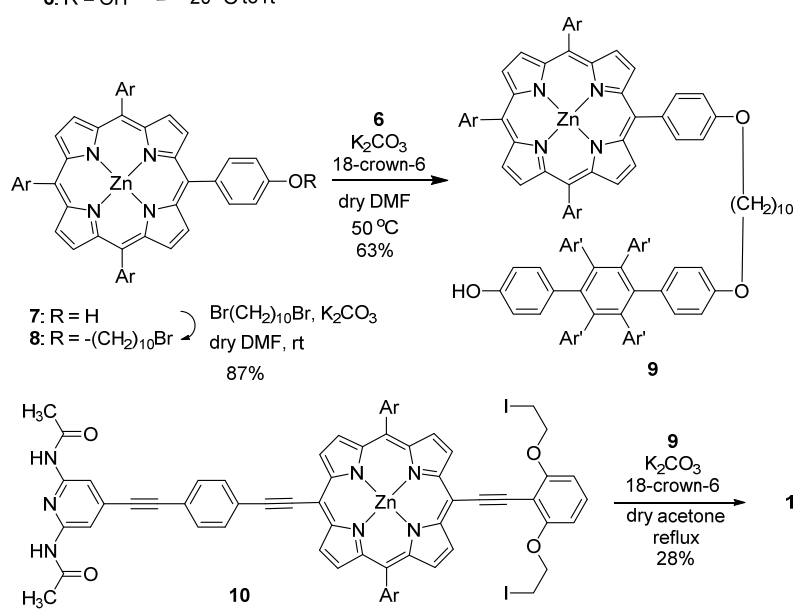

Scheme 1. Synthesis of receptor 1 
The synthesis of $\mathbf{1}$ is summarized in Scheme 1. Hexaarylbenzene 6 was obtained from hexabromobenzene (3) using the method reported for the synthesis of hexaarylbenzene derivatives. ${ }^{[8]}$ The reaction of porphyrin $7^{[9]}$ with excess 1,10 dibromodecane under basic conditions afforded porphyrin 8 . Substitution of the bromo group in porphyrin $\mathbf{8}$ with one of the two hydroxyl groups in hexaarylbenzene $\mathbf{6}$ was carried out using the Williamson ether synthesis conditions. Side arm $\mathbf{9}$ and main rod 10 were heated in acetone in the presence of potassium carbonate and 18 -crown- 6 to produce 1 in $28 \%$ yield. The structure of 1 was unambiguously characterized by NMR (Figures S6-S11) and MALDI-TOF MS analyses (Figure S28).

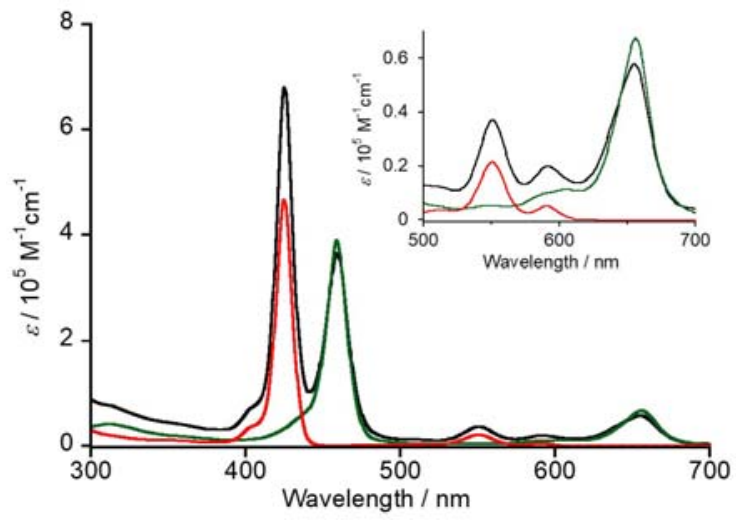

Figure 4. UV-vis spectra of $\mathbf{1 ,} \mathbf{9}$, and 10 in toluene at $25^{\circ} \mathrm{C}$

UV-vis spectra of 1,9 , and 10 in toluene at $25^{\circ} \mathrm{C}$ are displayed and compared in Figure 4. A solution of 1 showed a couple of intense absorption bands at $425(\log \varepsilon=5.83)$ and $459 \mathrm{~nm}(\log \varepsilon$ $=5.56$ ) that are attributed to the Soret bands of P1 and P2, respectively. ${ }^{[10]}$ Three absorption bands with relatively weak intensity were observed at $\lambda_{\max }=551(\log \varepsilon=4.64), 592(\log \varepsilon=$ 4.34), and $655 \mathrm{~nm}(\log \varepsilon=4.88)$. These bands were reasonably assigned to the Q-band of P1, overlapped absorption of the Qbands of $\mathrm{P} 1$ and $\mathrm{P} 2$, and the $\mathrm{Q}$-band of $\mathrm{P} 2$, respectively. ${ }^{[10]}$ These characteristic bands are useful to monitor the ligand binding to $\mathrm{P} 1$ and $\mathrm{P} 2$ at the same time (vide infra).

First, we investigated the stability of $\mathbf{1 \cdot 2}$ in toluene (Figure S3). Figure 5(a) shows the absorption spectral change of the solution of $1\left(9.98 \times 10^{-6} \mathrm{M}\right)$ observed after adding up to 1.0 equivalent of $2\left(6.05 \times 10^{-4} \mathrm{M}\right)$. The peak intensities at 551 and $655 \mathrm{~nm}$ decreased, and a couple of absorption bands appeared at 563 and $604 \mathrm{~nm}$. During the addition, an isobestic point were observed at $558 \mathrm{~nm}$. It has been established that axial coordination of ligands with zinc porphyrins produces absorption bands in longer wavelength region compared to the corresponding bands of ligand-free zinc porphyrins. ${ }^{[11]}$ The observed absorption change indicates the axial coordination of PY on the zinc atom of P1. On the other hand, blue shift and a decrease in intensity were observed at $\lambda_{\max }=655 \mathrm{~nm}$ which is assigned to $\mathrm{P} 2$, indicating the interaction between the shielding panel and $P 2 .{ }^{[6]}$ The coordination between $P Y$ and $P 2$ is insignificant under these conditions because of the negligible intensity of a characteristic band in the wavelength region longer than $655 \mathrm{~nm}$ by the axial coordination. ${ }^{[11]}$ The binding constant of 1.2 was evaluated as $K_{1.2}=6.73 \pm 0.67 \times 10^{6} \mathrm{M}^{-1}$ from the global curve-fitting by the theoretical curves obtained from the $1: 1$ binding model $(\mathbf{1}+\mathbf{2} \rightleftarrows \mathbf{1 \cdot 2}) \cdot{ }^{[12]}$ These results indicate the nearly quantitative formation of $\mathbf{1 \cdot 2}$ under these conditions. The large binding constant between $\mathbf{1}$ and $\mathbf{2}$ indicates that the $\mathrm{HU}$ DAP hydrogen bonds and the PY-P1 coordination bonds were cooperatively formed under these conditions.
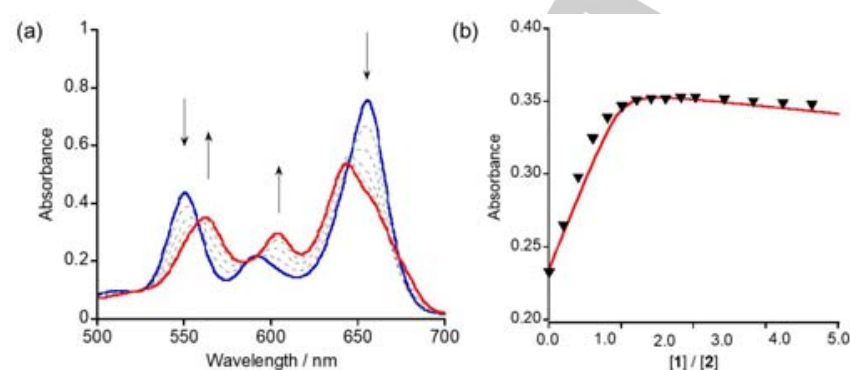

Figure 5. (a) UV-vis spectral titration data of $1\left(9.98 \times 10^{-6} \mathrm{M}\right)$ with $2(6.05 \times$ $10^{-4} \mathrm{M}$ ) in toluene at $25^{\circ} \mathrm{C}$ ( 0 equiv: blue line, 1.0 equiv: red line) (b) The change in the absorbance at 563 (black Inverted triangle) as a function of relative concentration of $\mathbf{2}$. The red solid lines are theoretical binding curves obtained by the curve fittings.

(a)
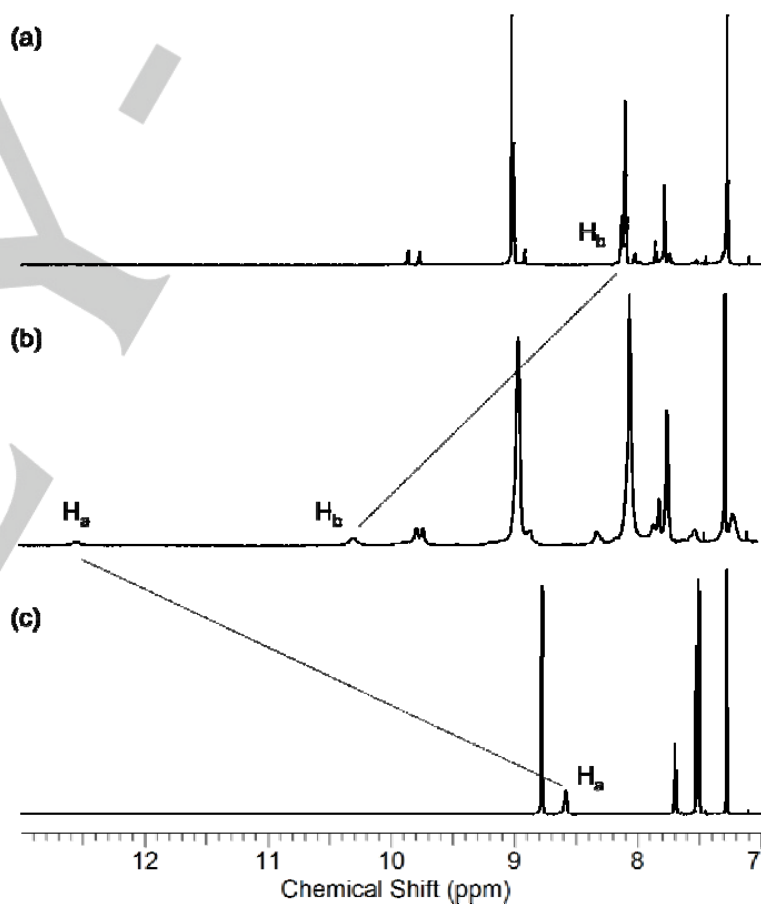

Figure 6. Partial ${ }^{1} \mathrm{H}$ NMR spectra of (a) $\mathbf{1}$, (b) $\mathbf{1} \cdot 2$ and (c) 2 in $\mathrm{CDCl}_{3}$.

To obtain further insight into the binding of 1 and $2,{ }^{1} \mathrm{H}$ NMR of $\mathbf{1 \cdot 2}$ was measured in $\mathrm{CDCl}_{3}$ (Figures $\mathrm{S} 12-\mathrm{S} 15$ ). NMR spectra of $\mathbf{1}, \mathbf{2}$, and $\mathbf{1 \cdot 2}$ are displayed and compared in Figure 6 . The $\mathrm{N}-\mathrm{H}$ protons $\mathrm{H}_{\mathrm{a}}(10.3 \mathrm{ppm})$ and $\mathrm{H}_{\mathrm{b}}(12.5 \mathrm{ppm})$ in $\mathbf{1 \cdot 2}$ resonated in the lower magnetic field as compared to the $\mathrm{N}-\mathrm{H}$ proton in $\mathbf{1}(8.12$ $\mathrm{ppm})$ and $2(8.63 \mathrm{ppm})$, respectively, indicating the formation of multiple hydrogen bonds between DAP and HU. ${ }^{[13]}$ The NOESY spectrum of $\mathbf{1 . 2}$ (Figure $\mathrm{S} 1$ ) revealed a clear cross-peak between these signals, indicating that protons $\mathrm{H}_{a}$ and $\mathrm{H}_{b}$ are close to each other. In addition, the NOESY spectrum of $\mathbf{1 \cdot 2}$ (Figure S2) showed cross-peaks between the signals of aromatic protons in the shielding panel and the signals of $\beta$ protons of $\mathrm{P} 2$, suggesting that they were in close proximately. 
These results are consistent with the quantitative formation of $\mathbf{1 \cdot 2}$, where the shielding panels cover both faces of $P 2$.

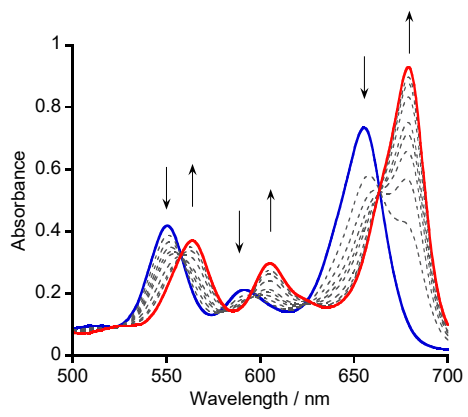

Figure 7. UV-vis spectral change resulting from the titration of $1\left(9.81 \times 10^{-6}\right.$ M) with 4-phenylpyridine in toluene at $25^{\circ} \mathrm{C}$ ( 0 equiv: blue line, 100 equiv: red line).
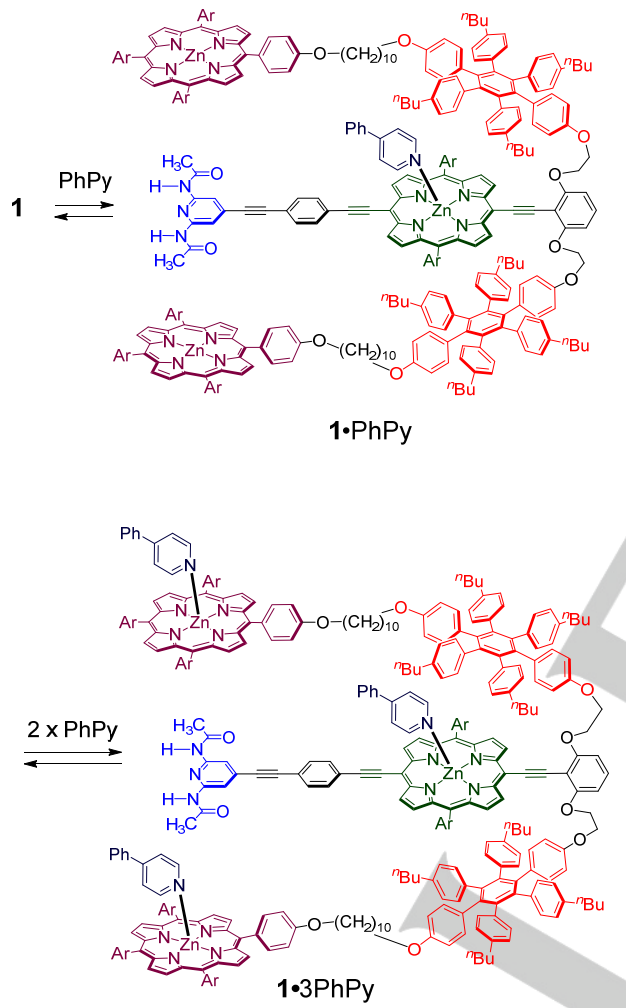

Figure 8 . Stepwise formation of $1 \cdot 3 \mathrm{PhPy}$ from 1 via $1 \cdot \mathrm{PhPy}$.

UV-vis spectroscopic titrations using 4-phenylpyridine (PhPy) as a ligand were performed in toluene at $25{ }^{\circ} \mathrm{C}$ to evaluate the ligand-binding ability of P2 in 1 in the absence and presence of 2 An aliquot of the PhPy solution $\left(5.97 \times 10^{-3} \mathrm{M}\right)$, up to 100 equivalent, was added to the solution of $1\left(9.81 \times 10^{-6} \mathrm{M}\right)$ and the changes in absorption were recorded as shown in Figure 7 (Figure S4). The absorption bands observed at $\lambda_{\max }=551,594$, and $655 \mathrm{~nm}$ before the addition decreased in intensity and new bands appeared at $\lambda_{\max }=563,605$, and $679 \mathrm{~nm}$. Isobestic points were observed at 558,625 , and $664 \mathrm{~nm}^{[6]}$ These results indicate that PhPy coordinates with both P1 and P2 in 1. The coordination reaction was analyzed according to the stepwise reaction model in Figure 8 by global curve-fitting calculations. ${ }^{[10]}$ The binding constant between P2 in 1 and $\mathrm{PhPy}\left(K_{1 \cdot \mathrm{PhPy}}\right.$, eq 1$)$ was determined as $4.75 \pm 0.02 \times 10^{4} \mathrm{M}^{-1}$. Formation constant $\left(\beta_{1 \cdot 3 \mathrm{PhPy}}\right.$, eq 2$)$ from $1 \cdot \mathrm{PhPy}$ to $1 \cdot 3 \mathrm{PhPy}$ was estimated as $4.14 \pm$ $0.05 \times 10^{7} \mathrm{M}^{-2}$.

$$
\begin{aligned}
& K_{1 \cdot \mathrm{PyPh}}=[1 \cdot \mathrm{PhPy}] /([1][\mathrm{PhPy}]) \\
& \beta_{1 \cdot 3 \mathrm{PhPy}}=[1 \cdot 3 \mathrm{PyPh}] /\left([1 \cdot \mathrm{PhPy}][\mathrm{PhPy}]^{2}\right)
\end{aligned}
$$

UV-vis titrations were also performed to determine the binding constants of $\mathrm{P} 2$ in $\mathbf{1 \cdot 2}$ with $\mathrm{PhPy}$ (Figure S5). The solution of $\mathbf{1 \cdot 2}$ was prepared by adding the solution of $2\left(6.08 \times 10^{-4} \mathrm{M}\right)$ to the solution of $1\left(9.81 \times 10^{-6} \mathrm{M}\right)$. The solution of PhPy $\left(5.97 \times 10^{-3}\right.$ M) was added to the solution of $\mathbf{1 \cdot 2}$, up to 100 equivalent, and the spectral change was monitored (Figure 9). The band of P2 at $\lambda_{\max }=643 \mathrm{~nm}$ ( 0 equiv) disappeared and a new band at $\lambda_{\max }=$ $679 \mathrm{~nm}$ (100 equiv) appeared in the titration, indicating the axial coordination of PhPy to P2 in 1. On the contrary, an insignificant change was observed for the bands at $\lambda_{\max }=551 \mathrm{~nm}$ where P1 with Py has a dominant absorption. An isobestic point was clearly observed at $658 \mathrm{~nm}$. Overall, these results suggested that the binding between 1 and $\mathbf{2}$ was maintained in the titration and also the coordination of PhPy to $\mathrm{P} 1$ was inhibited in a competitive manner. The 1:1 binding model in Figure 10 was successfully applied to reproduce the observed spectral change by global curve-fitting calculations. The binding constant $K_{1 \cdot 2 \cdot P h P y}$ (eq 3) was evaluated as $4.23 \pm 0.02 \times 10^{3} \mathrm{M}^{-1}$.

$$
K_{1 \cdot 2 \cdot P h P y}=[1 \cdot 2 \cdot P h P y] /([1 \cdot 2][P h P y])
$$

The ratio of the binding constant between ligand and receptor ( $\left.K_{1 \text {.2. } \mathrm{PhPy}} / K_{1 \text { 1. PhPy }}\right)$ was employed to evaluate the degree of inhibition for the binding between PhPy and P2 in $\mathbf{1 \cdot 2}$ compared to that of 1 . The smaller values of $K_{1 \cdot 2 \cdot \mathrm{PhPy}} / K_{1}$. PhPy indicate stronger inhibition. The $K_{1 \cdot 2 \cdot p_{p h y}} / K_{1 \cdot p h P y}$ was calculated as 0.089 that is significantly smaller than that of the previously reported receptor (0.24). ${ }^{[6]}$ In spite of the conformal flexibility of the side chains, the sterically bulky shielding panels significantly enhanced the degree of allosteric inhibition. These results established that hexaarylbenzene groups are superior shielding units for covering both faces of P2 to inhibit the axial-ligand coordination on $\mathrm{P} 2$.
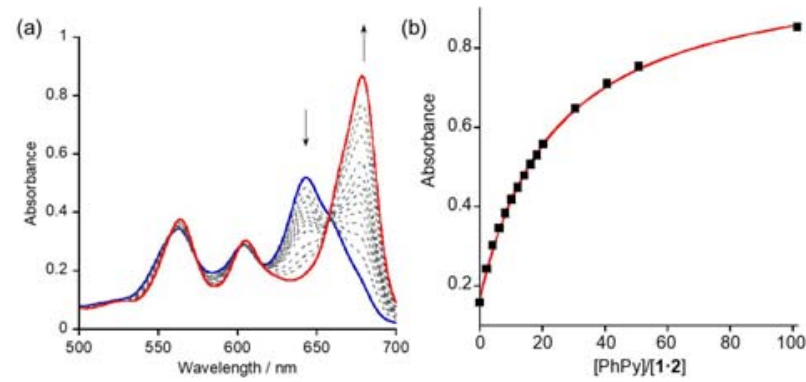

Figure 9. (a) UV-vis spectral change resulting from the titration of $\mathbf{1 \cdot 2}(9.65 \times$ $10^{-6} \mathrm{M}$ ) with 4-phenylpyridine in toluene at $25^{\circ} \mathrm{C}$ (blue line: 0 equiv, red line: 100 equiv). (b) The change in the absorbance at $679 \mathrm{~nm}$ as a function of concentration of 4-phenylpyridine (black square). The red solid line is a theoretical binding curve obtained by the curve fitting. 


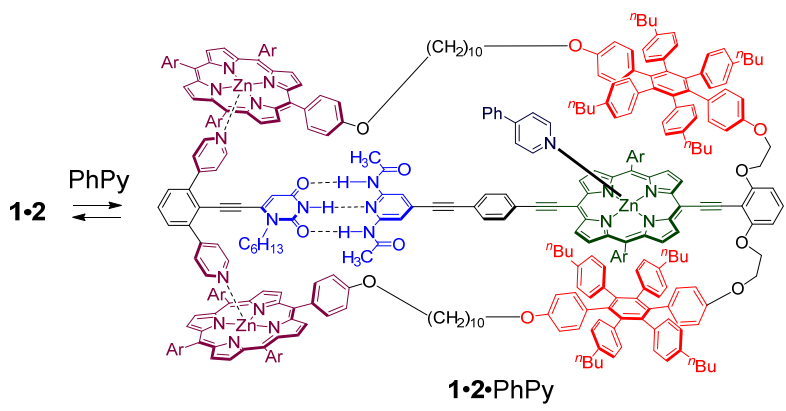

Figure 10. Formation of $\mathbf{1 \cdot 2} \cdot \mathrm{PhPy}$ from $\mathbf{1 \cdot 2}$ and $\mathrm{PhPy}$.

\section{Conclusion}

The stimulus-responsive receptor 1 comprising two types of zinc porphyrins $\mathrm{P} 1$ and $\mathrm{P} 2$ as active sites was prepared. Simultaneous formation of multiple hydrogen and coordination bonds between the receptor $\mathbf{1}$ and the organic effector $\mathbf{2}$, produced the stable supramolecular complex. The ligandbinging ability of $\mathrm{P} 1$ was competitively inhibited owing to the high stability of the complex. The multiple supramolecular bonds provided enough driving force for the conformational transformation that plays a key role in allosteric inhibition of P2 activity. The incorporation of sterically bulky shielding units results in considerable enhancement in the degree of allosteric inhibition. The stimulus-responsive shielding for allosteric inhibition presented in this paper is extensively applicable for the development of receptors that can respond to neutral organic effectors. It is notable that only an organic molecule with a specific structure can play as an effector in this system. This feature is also characteristic advantage of the molecular recognition by multiple bonding interactions.

\section{Experimental Section}

\section{General Information}

Melting points were taken on Yanako MP J-3 apparatus and are uncorrected. NMR spectra were recorded on JEOL JNM-ECZ 400, Bruker AV $300 \mathrm{~N}$, and Bruker AV III HD 400 spectrometers. IR spectra were obtained on a JASCO FTIR-4600 spectrometer. The ESI mass was measured on a JEOL AccuTOF LC-plus 4G spectrometer. MALDI-TOF mass was measured on Shimadzu-Kratos AXIMA-CFR Plus and BURUKER solariX spectrometers using dithranol as a matrix reagent. Elemental analyses were obtained from the Analytical Center in Osaka City University. UV-vis spectra were obtained on Shimadzu UV-2550PC spectrometer. TLC was carried out using $0.25 \mathrm{~mm}$ thick Wako silica gel (70 F254). Kanto kagaku silica gel 60 (spherical) were used as the stationary phase for column chromatography. Zinc porphyrin 7 was prepared according to the reported methods. ${ }^{[9]}$ Commercially available reagents and solvents were purified and dried when necessary.

\section{1,4-Diiodo-2,3,5,6-tetrakis(4-butylphenyl)benzene (4)}

Mg turnings $(7.81 \mathrm{~g}, 321 \mathrm{mmol})$ were placed in a three-necked flask under a nitrogen atmosphere. After anhydrous THF $(150 \mathrm{~mL})$ was added to the flask, 1-bromo-4-butylbenzene $(19.0 \mathrm{~mL}, 111 \mathrm{mmol})$ was added dropwise in an ice bath. The mixture was stirred at room temperature for
$2 \mathrm{~h}$. The solution was decanted into another flask for leaving excess $\mathrm{Mg}$, and hexabromobenzene (3) $(5.02 \mathrm{~g}, 9.11 \mathrm{mmol})$ in $50 \mathrm{~mL}$ anhydrous THF was added to the flask. The mixture was stirred at room temperature for $22 \mathrm{~h}$. The mixture was quenched with a $1 \mathrm{M}$ solution of iodine in THF $(58.0 \mathrm{~mL}, 58.0 \mathrm{mmol})$ and stirred for $15 \mathrm{~min}$. Excess iodine was consumed by the addition of $1 \mathrm{M}$ aqueous $\mathrm{Na}_{2} \mathrm{SO}_{3}$ and the mixture was extracted from $\mathrm{CH}_{2} \mathrm{Cl}_{2}(400 \mathrm{~mL})$. The organic layer was washed with water $(200 \mathrm{~mL} \times 2)$ and dried over anhydrous $\mathrm{Na}_{2} \mathrm{SO}_{4}$. The solvent was evaporated under reduced pressure to yield 4 as a white solid $(3.86 \mathrm{~g}$, 49\%). 4: m.p. > $300{ }^{\circ} \mathrm{C} ;{ }^{1} \mathrm{H}$ NMR (300 MHz, $\mathrm{CDCl}_{3}$ ): $\delta$ (ppm) 6.94 (d, J = $8.3 \mathrm{~Hz}, 8 \mathrm{H}$; Ar-H), 6.90 (d, J = 8.3 Hz, 8H; Ar-H), 2.50 (t, J = 7.6 Hz, 8H; $\mathrm{ArCH}_{2}$ ), $1.51-1.44\left(\mathrm{~m}, 8 \mathrm{H} ; \mathrm{CH}_{2}\right), 1.22-1.16$ (sext, $\mathrm{J}=7.4 \mathrm{~Hz}, 8 \mathrm{H} ; \mathrm{CH}_{2}$ ), $0.871\left(\mathrm{t}, \mathrm{J}=7.4 \mathrm{~Hz}, 12 \mathrm{H} ; \mathrm{CH}_{3}\right) ;{ }^{13} \mathrm{C} \mathrm{NMR}\left(100 \mathrm{MHz} \mathrm{CDCl}_{3}\right): \delta(\mathrm{ppm})$ $146.6,143.1,141.3,129.8,127.4,108.4,35.3,33.5,22.2,14.1$; IR $\left(\mathrm{KBr} / \mathrm{cm}^{-1}\right)$ 3047, 3025, 2957, 2926, 2871, 2856, 2357, 2341, 2322, 1516 , 1457, 1406, 1376, 1212, 1115, 1026, 833, 644, 553; HRMS (ESI+): calcd for $\mathrm{C}_{46} \mathrm{H}_{53} \mathrm{I}_{2} \mathrm{~m} / \mathrm{z}$ 859.2237; found $\mathrm{m} / \mathrm{z} 859.2232$.

\section{4,4"-Butyl-4',5'-bis(4-butylphenyl)-3',6'-bis(4-methoxyphenyl)- 1,1':2',1"-terphenyl (5)}

A mixture of $4(2.02 \mathrm{~g}, 2.35 \mathrm{mmol}), 4-$ methoxyphenylboronic acid $(1.39 \mathrm{~g}$, $9.21 \mathrm{mmol}), \mathrm{Pd}\left(\mathrm{PPh}_{3}\right)_{4}(134 \mathrm{mg}, 0.116 \mathrm{mmol}), \mathrm{K}_{2} \mathrm{CO}_{3}(6.42 \mathrm{~g}, 46.5$ $\mathrm{mmol}$ ), and trioctylmethylammonium chloride (aliquat $336,28.0 \mathrm{mg}$, $0.0693 \mathrm{mmol})$ in degassed toluene $(70 \mathrm{~mL})$ were stirred at $100{ }^{\circ} \mathrm{C}$ for $7 \mathrm{~h}$ under a nitrogen atmosphere. After cooling to room temperature, the mixture was extracted with $\mathrm{CH}_{2} \mathrm{Cl}_{2}(200 \mathrm{~mL})$. The organic layer was washed with water $(100 \mathrm{~mL} \times 3)$ and dried over anhydrous $\mathrm{Na}_{2} \mathrm{SO}_{4}$. The solvent was evaporated under reduced pressure. The residue was separated by silica gel column chromatography (hexane- $\mathrm{CH}_{2} \mathrm{Cl}_{2} \quad 4: 1$ $(v / v))$ to yield 5 as a yellow solid $(1.90 \mathrm{~g}, 98 \%)$. 5: m.p. $94{ }^{\circ} \mathrm{C} ;{ }^{1} \mathrm{H}$ NMR (300 MHz, $\left.\mathrm{CDCl}_{3}\right): \delta(\mathrm{ppm}) 6.70-6.61(\mathrm{~m}, 20 \mathrm{H} ; \mathrm{Ar}-\mathrm{H}), 6.38(\mathrm{~d}, \mathrm{~J}=8.7 \mathrm{~Hz}$, $4 \mathrm{H} ; \mathrm{Ar}-\mathrm{H}$ in $\left.\mathrm{C}_{6} \mathrm{H}_{4} \mathrm{OMe}\right), 3.60\left(\mathrm{~s}, 6 \mathrm{H} ; \mathrm{OCH}_{3}\right), 2.36(\mathrm{t}, \mathrm{J}=7.3 \mathrm{~Hz}, 8 \mathrm{H}$; $\mathrm{ArCH}_{2}$ ), 1.40 (quin, $\mathrm{J}=7.3 \mathrm{~Hz}, 8 \mathrm{H} ; \mathrm{CH}_{2}$ ), 1.14 (sext, $\mathrm{J}=7.3 \mathrm{~Hz}, 8 \mathrm{H} ; \mathrm{CH}_{2}$ ), $0.827\left(\mathrm{t}, J=7.3 \mathrm{~Hz}, 12 \mathrm{H} ; \mathrm{CH}_{3}\right) ;{ }^{13} \mathrm{C}$ NMR $\left(100 \mathrm{MHz}, \mathrm{CDCl}_{3}\right): \delta(\mathrm{ppm})$ $156.9,140.7,139.1,138.4,133.6,132.6,131.4,126.7,112.0,55.0,35.1$, 33.5, 21.9, 14.1; IR $\left(\mathrm{KBr} / \mathrm{cm}^{-1}\right)$ 3047, 3021, 2997, 2955, 2928, 2857, 1610, 1516, 1458, 1287, 1245, 1173, 1038, 1027, 831, 799, 569, 553; HRMS (ESI+): calc for $\mathrm{C}_{60} \mathrm{H}_{67} \mathrm{O}_{2} \mathrm{~m} / \mathrm{z} 819.5141$; found $\mathrm{m} / \mathrm{z} 819.5168$.

\section{2',3',5',6'-Tetrakis(4-butylphenyl)-[1,1':4',1"-terphenyl]-4,4"-diol (6)}

The solution of $\mathrm{BBr}_{3}$ in $\mathrm{CH}_{2} \mathrm{Cl}_{2}(1.0 \mathrm{M}, 4.1 \mathrm{~mL}, 4.1 \mathrm{mmol})$ was added dropwise to $5(590 \mathrm{mg}, 0.720 \mathrm{mmol})$ in anhydrous $\mathrm{CH}_{2} \mathrm{Cl}_{2}(135 \mathrm{~mL})$ at $-20{ }^{\circ} \mathrm{C}$ under a nitrogen atmosphere. After stirring at room temperature for $7 \mathrm{~h}$, the mixture was washed with water $(100 \mathrm{~mL} \times 3)$ and dried over anhydrous $\mathrm{Na}_{2} \mathrm{SO}_{4}$. The solvent was evaporated under reduced pressure to yield 6 as a yellow solid (565 mg, 99\%). 6: m.p. $250-252{ }^{\circ} \mathrm{C} ;{ }^{1} \mathrm{H}$ NMR (300 MHz, $\left.\mathrm{CDCl}_{3}\right): \delta(\mathrm{ppm}) 6.66-6.63(\mathrm{~m}, 20 \mathrm{H} ; \mathrm{Ar}-\mathrm{H}), 6.31(\mathrm{~d}, \mathrm{~J}=8.7 \mathrm{~Hz}$, $4 \mathrm{H}$; $\mathrm{Ar}-\mathrm{H}$ in $\left.\mathrm{C}_{6} \mathrm{H}_{4} \mathrm{OH}\right), 4.26(\mathrm{~s}, 2 \mathrm{H} ; \mathrm{OH}), 2.36\left(\mathrm{t}, \mathrm{J}=7.4 \mathrm{~Hz}, 8 \mathrm{H} ; \mathrm{ArCH}_{2}\right.$ ), 1.40 (quin, $J=7.4 \mathrm{~Hz}, 8 \mathrm{H}$; $\mathrm{CH}_{2}$ ), 1.15 (sext, $\mathrm{J}=7.4 \mathrm{~Hz}, 8 \mathrm{H} ; \mathrm{CH}_{2}$ ), 0.83 (t, $\left.\mathrm{J}=7.4 \mathrm{~Hz}, 12 \mathrm{H} ; \mathrm{CH}_{3}\right) ;{ }^{13} \mathrm{C}$ NMR $\left(100 \mathrm{MHz} \mathrm{CDCl}_{3}\right): \delta$ (ppm) 152.7, 140.6, 139.2, 138.3, 133.8, 132.8, 131.4, 126.7, 113.6, 35.1, 33.4, 22.0, 14.1; IR $\left(\mathrm{KBr} / \mathrm{cm}^{-1}\right)$ 3537, 3399, 3024, 2955, 2928, 2871, 2857, 2361, 1900, 1611, 1592, 1517, 1458, 1439, 1420, 1396, 1378, 1263, 1171, 1115, 1101, 1019, 856, 833, 754, 546; HRMS (ESI+): calc for $\mathrm{C}_{58} \mathrm{H}_{63} \mathrm{O}_{2} \mathrm{~m} / \mathrm{z}$ 791.4828 ; found $\mathrm{m} / \mathrm{z} 791.4857$

\section{Zinc tetraphenylporphyrin 8}

A mixture of porphyrin $7^{[9]}(200 \mathrm{mg}, 0.194 \mathrm{mmol}), 1,10$-dibromodecane $(0.44 \mathrm{~mL}, 1.95 \mathrm{mmol})$, and $\mathrm{K}_{2} \mathrm{CO}_{3}(42.0 \mathrm{mg}, 0.304 \mathrm{mmol})$ in anhydrous DMF $(20 \mathrm{~mL})$ were stirred at room temperature for $13 \mathrm{~h}$ under a nitrogen atmosphere. The mixture was extracted with $\mathrm{CH}_{2} \mathrm{Cl}_{2}(40 \mathrm{~mL})$. The organic solution was washed with saturated solution of $\mathrm{NH}_{4} \mathrm{Cl}(20 \mathrm{~mL} \times$ 2) and water $(20 \mathrm{~mL} \times 2)$ and dried over anhydrous $\mathrm{Na}_{2} \mathrm{SO}_{4}$. The solvent was evaporated under reduced pressure. The residue was washed with $\mathrm{MeOH}(40 \mathrm{~mL})$ to yield 8 as a purple solid (212 mg, 87\%). 8: m.p. 
$291{ }^{\circ} \mathrm{C} ;{ }^{1} \mathrm{H}$ NMR $\left(400 \mathrm{MHz}, \mathrm{CDCl}_{3}\right): \delta(\mathrm{ppm}) 8.99(\mathrm{~d}, \mathrm{~J}=4.2 \mathrm{~Hz}, 8 \mathrm{H} ; \beta-\mathrm{H})$, $8.13\left(\mathrm{~d}, \mathrm{~J}=8.6 \mathrm{~Hz}, 2 \mathrm{H}\right.$; $\mathrm{Ar}-\mathrm{H}$ in $\left.\mathrm{C}_{6} \mathrm{H}_{4} \mathrm{OR}\right), 8.09(\mathrm{~d}, \mathrm{~J}=1.8 \mathrm{~Hz}, 4 \mathrm{H} ; \mathrm{Ar}-\mathrm{H}$ in 3,5- $\left.{ }^{\mathrm{t}} \mathrm{BuC}_{6} \mathrm{H}_{3}\right), 8.08\left(\mathrm{~d}, \mathrm{~J}=1.8 \mathrm{~Hz}, 2 \mathrm{H}\right.$; $\mathrm{Ar}-\mathrm{H}$ in $\left.3,5-{ }^{t} \mathrm{BuC}_{6} \mathrm{H}_{3}\right), 7.78(\mathrm{~m}, 3 \mathrm{H}$; $\mathrm{Ar}-\mathrm{H}$ in $\left.3,5-{ }^{-} \mathrm{BuC}_{6} \mathrm{H}_{3}\right), 7.27\left(\mathrm{~d}, \mathrm{~J}=8.6 \mathrm{~Hz}, 2 \mathrm{H}\right.$; $\mathrm{Ar}-\mathrm{H}$ in $\left.\mathrm{C}_{6} \mathrm{H}_{4} \mathrm{OR}\right) 4.26$ (t, J $=5.1 \mathrm{~Hz}, 2 \mathrm{H} ; \mathrm{OCH}_{2}$ ), $3.44\left(\mathrm{t}, \mathrm{J}=5.3 \mathrm{~Hz}, 2 \mathrm{H} ; \mathrm{CH}_{2} \mathrm{Br}\right.$ ), 1.99 (quin, $\mathrm{J}=5.1$ $\mathrm{Hz}, 2 \mathrm{H} ; \mathrm{CH}_{2}$ ), 1.90 (quin, $\left.\mathrm{J}=5.3 \mathrm{~Hz}, 2 \mathrm{H} ; \mathrm{CH}_{2}\right), 1.69-1.59\left(\mathrm{~m}, 2 \mathrm{H} ; \mathrm{CH}_{2}\right.$ ), $1.52\left(\mathrm{~s}, 54 \mathrm{H} ;{ }^{t} \mathrm{Bu}\right), 1.42-1.24\left(\mathrm{~m}, 10 \mathrm{H} ; \mathrm{CH}_{2}\right) ;{ }^{13} \mathrm{C} \mathrm{NMR}\left(100 \mathrm{MHz}, \mathrm{CDCl}_{3}\right)$ : $\delta(\mathrm{ppm}) 158.8,150.6,150.5,148.6,142.0,135.4,135.3,132.3,132.0$, 129.8, 129.7, 122.5, 120.9, 112.7, 68.4, 35.2, 34.3, 33.0, 31.9, 31.6, 29.7 29.6, 29.6, 28.9, 28.3, 26.4; IR $\left(\mathrm{KBr} / \mathrm{cm}^{-1}\right) 3444,2962,2859,2360,2341$, 1592, 1509, 1474, 1362, 1339, 1290, 1247, 1222, 1173, 1001, 823, 799, 718; HRMS (MALDI-TOF): calcd for $\mathrm{C}_{78} \mathrm{H}_{95} \mathrm{~N}_{4} \mathrm{OZn} \mathrm{m} / \mathrm{z}$ 1246.5975; found $m / z 1246.5969$

\section{Side arm 9}

A mixture of $6(750 \mathrm{mg}, 0.948 \mathrm{mmol}), 8(300 \mathrm{mg}, 0.240 \mathrm{mmol}), \mathrm{K}_{2} \mathrm{CO}_{3}$ (165 mg, $1.20 \mathrm{mmol}$ ), and 18-crown-6 (16 mg, $0.0667 \mathrm{mmol}$ ) in anhydrous DMF $(30 \mathrm{~mL})$ were stirred at $50{ }^{\circ} \mathrm{C}$ for $23 \mathrm{~h}$ under a nitrogen atmosphere. The organic solution was washed with saturated solution of $\mathrm{NH}_{4} \mathrm{Cl}(60 \mathrm{~mL} \times 2)$ and water $(60 \mathrm{~mL} \times 2)$ and dried over anhydrous $\mathrm{Na}_{2} \mathrm{SO}_{4}$. The solvent was evaporated under reduced pressure. The residue was purified by silica gel column chromatography (hexane$\mathrm{CH}_{2} \mathrm{Cl}_{2}$ 1:1 (v/v)) to yield 9 as a purple solid (294 mg, 63\%). 9: m.p. $180{ }^{\circ} \mathrm{C} ;{ }^{1} \mathrm{H}$ NMR $\left(400 \mathrm{MHz}, \mathrm{CDCl}_{3}\right): \delta(\mathrm{ppm}) 8.99(\mathrm{~d}, \mathrm{~J}=4.5 \mathrm{~Hz}, 8 \mathrm{H} ; \beta-\mathrm{H})$ $8.12\left(\mathrm{~d}, \mathrm{~J}=8.6 \mathrm{~Hz}, 2 \mathrm{H}\right.$; Ar-H in Porphyrin- $\left.\mathrm{C}_{6} \mathrm{H}_{4} \mathrm{OR}\right), 8.09$ (d, J = $1.8 \mathrm{~Hz}$, $4 \mathrm{H}$; $\mathrm{Ar}-\mathrm{H}$ in $\left.3,5-{ }^{\mathrm{t}} \mathrm{BuC}_{6} \mathrm{H}_{3}\right), 8.08\left(\mathrm{~d}, \mathrm{~J}=1.8 \mathrm{~Hz}, 2 \mathrm{H}\right.$; Ar- $\mathrm{H}$ in $\left.3,5-{ }^{\mathrm{t}} \mathrm{BuC}_{6} \mathrm{H}_{3}\right)$, 7.79-7.78 (m, 3H; Ar- $\mathrm{H}$ in 3,5- $\left.{ }^{\mathrm{t}} \mathrm{BuC}_{6} \mathrm{H}_{3}\right), 7.27(\mathrm{~d}, \mathrm{~J}=8.6 \mathrm{~Hz}, 2 \mathrm{H} ; \mathrm{Ar}-\mathrm{H}$ in Porphyrin- $\left.\mathrm{C}_{6} \mathrm{H}_{4} \mathrm{OR}\right)$, 6.68-6.62 (m, 20H; Ar-H in ${ }^{n} \mathrm{BuC}_{6} \mathrm{H}_{4}$ and $\mathrm{OC}_{6} \mathrm{H}_{4}$ ), $6.39\left(\mathrm{~d}, \mathrm{~J}=8.8 \mathrm{~Hz}, 2 \mathrm{H}\right.$; $\mathrm{Ar}-\mathrm{H}$ in $\left.\mathrm{OC}_{6} \mathrm{H}_{4}\right), 6.30(\mathrm{~d}, \mathrm{~J}=8.6 \mathrm{~Hz}, 2 \mathrm{H}$; $\mathrm{Ar}-\mathrm{H}$ in $\left.\mathrm{C}_{6} \mathrm{H}_{4} \mathrm{OH}\right), 4.29(\mathrm{~s}, 1 \mathrm{H} ; \mathrm{OH}), 4.25\left(\mathrm{t}, \mathrm{J}=5.1 \mathrm{~Hz}, 2 \mathrm{H} ; \mathrm{OCH}_{2}\right), 3.75(\mathrm{t}, \mathrm{J}=$ $5.0 \mathrm{~Hz}, 2 \mathrm{H} ; \mathrm{OCH}_{2}$ ), 2.38-2.34 (m, 8H; $\mathrm{ArCH}_{2}$ ), 1.98 (quin, $\mathrm{J}=5.1 \mathrm{~Hz}, 2 \mathrm{H}$; $\left.\mathrm{CH}_{2}\right), 1.70-1.66\left(\mathrm{~m}, 2 \mathrm{H} ; \mathrm{CH}_{2}\right), 1.64-1.60\left(\mathrm{~m}, 2 \mathrm{H} ; \mathrm{CH}_{2}\right), 1.52\left(\mathrm{~s}, 54 \mathrm{H} ;{ }^{t} \mathrm{Bu}\right)$ 1.43-1.35 (m, 18H; CH$), 1.19\left(\mathrm{~m}, 8 \mathrm{H} ; \mathrm{CH}_{2}\right), 0.85-0.81\left(\mathrm{~m}, 12 \mathrm{H} ; \mathrm{CH}_{3}\right)$; ${ }^{13} \mathrm{C}$ NMR $\left(100 \mathrm{MHz}, \mathrm{CDCl}_{3}\right): \delta(\mathrm{ppm}) 158.7,156.3,152.6,150.4,150.3$, $148.5,141.9,140.5,140.5,139.7,139.5,139.0,139.0,138.3,135.3$, $135.1,133.7,133.3,132.7,132.5,132.1,131.8,131.3,129.7,129.6$, 126.6, 122.3, 120.7, 113.5, 112.6, 112.5, 71.0, 68.3, 67.7, 66.4, 61.4, $35.0,33.4,33.3,31.7,29.7,29.6,29.6,29.5,29.3,26.2,26.0,21.8,21.8$, 15.0, 14.0; IR $\left(\mathrm{KBr} / \mathrm{cm}^{-1}\right)$ 3444, 2955, 2928, 2858, 2360, 1608, 1592, 1515, 1466, 1393, 1362, 1339, 1286, 1244, 1173, 1001, 824, 798, 718, 547; HRMS (MALDI-TOF): calc for $\mathrm{C}_{136} \mathrm{H}_{156} \mathrm{~N}_{4} \mathrm{O}_{3} \mathrm{Zn} \mathrm{m} / \mathrm{z} 1957.1463$; found $m / z$ 1957.1448.

\section{Receptor 1}

Under a nitrogen atmosphere a mixture of side arm $9(110 \mathrm{mg}, 0.0561$ $\mathrm{mmol}$ ), main unit 10 ${ }^{[6]}$ (34mg, $\left.0.0226 \mathrm{mmol}\right), \mathrm{K}_{2} \mathrm{CO}_{3}(19 \mathrm{mg}, 0.138 \mathrm{mmol})$ and 18-crown-6 (4.1 mg, $0.0152 \mathrm{mmol})$ in anhydrous acetone $(4 \mathrm{~mL})$ were stirred at under reflux for $23 \mathrm{~h}$. The organic solution was washed with saturated solution of $\mathrm{NH}_{4} \mathrm{Cl}(60 \mathrm{~mL} \times 2)$ and water $(60 \mathrm{~mL} \times 2)$ and dried over anhydrous $\mathrm{Na}_{2} \mathrm{SO}_{4}$. The solvent was evaporated under reduced pressure. The residue was separated by silica gel column chromatography (hexane- $\mathrm{CH}_{2} \mathrm{Cl}_{2} 1: 1(\mathrm{v} / \mathrm{v})$ ) to yield 1 as a purple solid (33 mg, 28\%). 1: m.p. > $300{ }^{\circ} \mathrm{C} ;{ }^{1} \mathrm{H}$ NMR $\left(600 \mathrm{MHz}, \mathrm{CDCl}_{3}\right): \delta$ (ppm) 9.87 $(\mathrm{d}, \mathrm{J}=4.3 \mathrm{~Hz}, 2 \mathrm{H} ; \beta-\mathrm{H}$ in $\mathrm{P} 2), 9.77(\mathrm{~d}, \mathrm{~J}=4.3 \mathrm{~Hz}, 2 \mathrm{H} ; \beta-\mathrm{H}$ in $\mathrm{P} 2), 9.04-$ $8.98(\mathrm{~m}, 18 \mathrm{H} ; \beta-\mathrm{H}$ in $\mathrm{P} 1$ and $\mathrm{P} 2), 8.92(\mathrm{~d}, \mathrm{~J}=4.3 \mathrm{~Hz}, 2 \mathrm{H} ; \beta-\mathrm{H}$ in $\mathrm{P} 2)$, 8.14-8.06 (m, 22H; Ar-H in P1 and P2, NH), 8.02 (d, J = 7.8 Hz, 2H; ArH) 7.85 (br, 2H; Py-H), 7.82-7.77 (m, 8H; Ar-H in P1 and P2, Ar-H), 7.74 (d, $J=7.8 \mathrm{~Hz}, 2 \mathrm{H}$; Ar-H), $7.30(\mathrm{~m}, 1 \mathrm{H} ; \mathrm{Ar}-\mathrm{H}$ ), 7.27 (overlap with solvent peak, 4H; Ar-H in P1), $6.75(\mathrm{~d}, \mathrm{~J}=8.5 \mathrm{~Hz}, 2 \mathrm{H}$; Ar-H), 6.74-6.49 (m, 40H; $\mathrm{Ar}-\mathrm{H}$ in the shielding units), $6.40(\mathrm{~d}, \mathrm{~J}=8.9 \mathrm{~Hz}, 4 \mathrm{H} \mathrm{Ar}-\mathrm{H}$ in the shielding units), 6.31 (d, $\mathrm{J}=7.9 \mathrm{~Hz}, 4 \mathrm{H} \mathrm{Ar}-\mathrm{H}$ in the shielding units), $4.58(\mathrm{~m}, 4 \mathrm{H}$; $\left.\mathrm{OCH}_{2} \mathrm{CH}_{2} \mathrm{O}\right), 4.53\left(\mathrm{~m}, 4 \mathrm{H} ; \mathrm{OCH}_{2} \mathrm{CH}_{2} \mathrm{O}\right), 4.24$ (t, $\mathrm{J}=6.3 \mathrm{~Hz}, 4 \mathrm{H} ; \mathrm{OCH}_{2}$ ), 3.75 (t, $\left.\mathrm{J}=6.4 \mathrm{~Hz}, 4 \mathrm{H} ; \mathrm{OCH}_{2}\right), 2.40-2.30$ (m, 12H; $\left.\mathrm{ArCH}_{2}, \mathrm{CH}_{2}\right), 2.04-$ $1.94\left(\mathrm{~m}, 18 \mathrm{H} ; \mathrm{ArCH}_{2}, \mathrm{CH}_{2}, \mathrm{OCH}_{3}\right), 1.73-1.42\left(\mathrm{~m}, 152 \mathrm{H} ;{ }^{t} \mathrm{Bu}, 2 \times \mathrm{CH}_{2}\right)$, 1.42-1.20 (m, 12H; $\mathrm{CH}_{2}$ in $\left.{ }^{n} \mathrm{Bu}, 2 \times \mathrm{CH}_{2}\right), 1.40-1.17\left(\mathrm{~m}, 16 \mathrm{H} ; 2 \times \mathrm{CH}_{2}\right.$ in $\left.{ }^{n} \mathrm{Bu}\right), 1.17-0.99\left(\mathrm{~m}, 8 \mathrm{H} ; \mathrm{CH}_{2}\right.$ in $\left.{ }^{n} \mathrm{Bu}\right), 0.89-0.76\left(\mathrm{~m}, 2 \mathrm{OH} ; \mathrm{CH}_{2}, \mathrm{CH}_{3}\right.$ in $\left.{ }^{n} \mathrm{Bu}\right), 0.63-0.57\left(\mathrm{~m}, 12 \mathrm{H} ; \mathrm{CH}_{3}\right.$ in ${ }^{n} \mathrm{Bu}$ ), (see Figures $\mathrm{S} 9$ and $\mathrm{S} 10$ for peak assignment); ${ }^{13} \mathrm{C}$ NMR (100 MHz, $\left.\mathrm{CDCl}_{3}\right): \delta$ (ppm) 160.9, 158.8, 156.3, $155.7,152.1,151.9,150.5,150.4,150.4,149.1,148.8,148.5,141.9$, $141.3,140.4,139.7,139.5,138.9,138.8,138.3,138.2,135.3,135.2$ $134.2,133.4,133.1,132.6,132.5,132.3,132.1,131.8,131.5,131.3$, $131.2,130.0,129.7,129.59,126.57,126.5,124.3 .122 .3,121.0,120.7$ $113.0,112.7,112.6,111.2,68.3,67.8,66.3,35.1,35.0,34.8,33.3,33.1$, $31.9,31.8,29.7,29.59,29.57,29.5,29.4,29.3,26.3,26.1,24.6,22.7$ 21.8, 21.6, 14.1, 13.9, 13.8; IR $\left(\mathrm{KBr} / \mathrm{cm}^{-1}\right) 3428,2957,2928,2859,2360$, $2342,1735,1716,1608,1593,1557,1513,1465,1418,1362,1286$, 1242, 1173, 1112, 1068, 1001, 930, 825, 798, 717; MS (MALDI-TOF) $\mathrm{m} / \mathrm{z} 5169.0[\mathrm{M}+]$; Anal. Calcd. for $\mathrm{C}_{351} \mathrm{H}_{385} \mathrm{~N}_{15} \mathrm{O}_{10} \mathrm{Zn}_{3} \cdot \mathrm{H}_{2} \mathrm{O}: \mathrm{C}, 80.98 ; \mathrm{H}$, 7.53; N, 4.04; found: C, 80.74; $\mathrm{H}, 7.60 ; \mathrm{N}, 3.77$.

\section{UV-vis spectroscopic titration}

UV-vis absorption spectra were measured at $25^{\circ} \mathrm{C}$ using $1 \mathrm{~cm}$ quartz cuvettes. A solution of a receptor in toluene $(3.0 \mathrm{~mL}$, conc. in Table S1) was prepared by careful weighting using an analytical balance. The solution of $\mathbf{1 . 2}$ was prepared by adding the solution of $\mathbf{2}$ to the solution of 1 (Table S1, entry 3). Stock solutions of an external axial ligand in toluene (conc. in Table S1) were also prepared. The binding constant was determined according to the following procedure. The stock solution of the ligand was repeatedly added to the solution of the receptor in the cuvette by using a micro pipette ( $V_{\text {add }}$ in Table S1) and the solution was stirred. After each addition the cuvette was placed in the cell compartment of a spectrometer and allowed to come to temperature equilibrium. UV-vis absorption spectra were measured with a Shimadzu UV-2550PC spectrometer equipped with a temperature controller. This procedure was repeated until no change was recorded within the spectra. UV-vis spectrophotometric titrations were globally analysed by curvefitting the $500-700 \mathrm{~nm}$ region of spectra at $1 \mathrm{~nm}$ intervals using the software ReactLab EQUILIBRIA. ${ }^{[12]}$

\section{Acknowledgements}

This work was partially supported by Grant-in-Aid for Scientific Research (JSPS KAKENHI \#Grant Numbers, JP15H00956 (K.O.) JP17K05790 (M.K. and K.O.) and JP26102005 (S.S), JP17K05783 (S.S)).

Keywords: Porphyrinoids • Allosterism • Supramolecular chemistry $\bullet$ Receptors $\bullet$ Molecular recognition

[1] M. F. Perutz, Molecular Mechanisms of Cooperativity and Allosteric Regulation in Proteins, Cambridge University Press, 1990.

[2] (a) C. Kremer, A. Lützen, Chem.-Eur. J. 2013, 19, 6162-6196; (b) A. M. Lifschitz, M. S. Rosen, C. M. McGuirk, C. A. Mirkin, J. Am. Chem. Soc. 2015, 137, 7252-7261; (c) T. Nabeshima, Bull. Chem. Soc. Jpn. 2010 83, 969-991; (d) A. J. McConnell, C. S. Wood, P. P. Neelakandan, J. R. Nitschke, Chem. Rev. 2015, 115, 7729-7793; (e) N. Mittal, S. Pramanik, I. Paul, S. De, M. Schmittel, J. Am. Chem. Soc. 2017, 139, 4270-4273; (f) N. Mittal, M. S. Özer, M. Schmittel, Inorg. Chem. 2018, 57, 35793586; (g) I. Paul, A. Goswami, N. Mittal, M. Schmittel, Angew. Chem., Inter. Ed. 2018, 57, 354-358; Angew. Chem. 2018, 130, 360-364.

[3] (a) M. J. Wiester, P. A. Ulmann, C. A. Mirkin, Angew. Chem., Int. Ed. 2011, 50, 114-137; Angew. Chem. 2011, 123, 1453-1481; (b) M Kozaki, Y. Ninomiya, S. Suzuki, K. Okada, Tetrahedron Lett. 2013, 54, 3658-3661; (c) M. Schmittel, S. De, S. Pramanik, Angew. Chem., Int. Ed. 2012, 51, 3832-3836; Angew. Chem. 2012, 124, 3898-3902; (d) V. Marcos, A. J. Stephens, J. Jaramillo Garcia, A. L. Nussbaumer, S. L. Woltering, A. Valero, J. F. Lemonnier, I. J. Vitorica Yrezabal, D. A. Leigh, Science 2016, 352, 1555-1559; (e) M. Kato, E. Hashimoto, M. Kozaki, S. Suzuki, K. Okada, Tetrahedron Lett. 2012, 53, 309-312. 
[4] (a) H. Kawai, R. Katoono, K. Nishimura, S. Matsuda, K. Fujiwara, T. Tsuji, T. Suzuki, J. Am. Chem. Soc. 2004, 126, 5034-5035; (b) H. Sato K. Tashiro, H. Shinmori, A. Osuka, Y. Murata, K. Komatsu, T. Aida, J. Am. Chem. Soc. 2005, 127, 13086-13087; (c) J. Heo, C. A. Mirkin, Angew. Chem., Int. Ed. 2006, 45, 941-944; Angew. Chem. 2006, 118, 955-958; (d) J. Rio, S. Beeck, G. Rotas, S. Ahles, D. Jacquemin, N Tagmatarchis, C. Ewels, H. A. Wegner, Angew. Chem., Int. Ed. 2018, 57, 6930-6934; Angew. Chem. 2018, 130, 7046-7050; (e) S.-Y. Chang H.-Y. Jang, K.-S. Jeong, Chem. Eur. J. 2004, 10, 4358-4366; (f) J. S. Park, F. Le Derf, C. M. Bejger, V. M. Lynch, J. L. Sessler, K. A. Nielsen, C. Johnsen, J. O. Jeppesen, Chem. -Eur. J. 2010, 16, 848-854.

[5] H. J. Yoon, J. Kuwabara, J.-H. Kim, C. A. Mirkin, Science 2010, 330, 66-69.

[6] Y. Sasaki, S. Suzuki, K. Okada, M. Kozaki, Tetrahedron Lett. 2016, 57, 4082-4085.

[7] Y. Ninomiya, M. Kozaki, S. Suzuki, K. Okada, Bull. Chem. Soc. Jpn. 2014, 87, 1195-1201.

[8] (a) S. Shah, B. E. E. Eichler, R. C. Smith, P. P. Power, J. D. Protasiewicz, New. J. Chem. 2003, 27, 442-445; (b) X. Yang, X. Dou, K. Müllen, Chem. Asian J. 2008, 3, 759-766.

[9] (a) H. Yamada, H. Imahori, S. Fukuzumi, J. Mater. Chem. 2002, 12, 2034-2040; (b) M. Kozaki, A. Uetomo, S. Suzuki, K. Okada, Org. Lett. 2008, 10, 4477-4480.

[10] A. Uetomo, M. Kozaki, S. Suzuki, K. Yamanaka, O. Ito, K. Okada, J. Am. Chem. Soc. 2011, 133, 13276-13279.

[11] (a) R. Kimura, S. Suzuki, K. Okada, M. Kozaki, J. Org. Chem. 2017, 82 8917-8926; (b) M. Akisada, R. Kimura, Y. Tachi, S. Suzuki, K. Okada M. Kozaki, J. Org. Chem. 2018, 83, 9631-9640; (c) R. Kimura, S. Suzuki, K. Okada, M. Kozaki, Chem. Asian J. 2018, 13, 35-40.

[12] Program ReactLab Equilibria, Jplus consulting Pty Ltd. In the region with the higher [1]/[2] values, the absorption gradually decreased due to the dilution.

[13] (a) L. Đorđević, T. Marangoni, T. Miletić, J. Rubio-Magnieto, J. Mohanraj, H. Amenitsch, D. Pasini, N. Liaros, S. Couris, N. Armaroli, M. Surin, D. Bonifazi, J. Am. Chem. Soc. 2015, 137, 8150-8160; (b) K Hager, U. Hartnagel, A. Hirsch, Eur. J. Org. Chem. 2007, 1942-1956; (c) S. Shinoda, M. Ohashi, H. Tsukube, Chem.-Eur. J. 2007, 13, 81-89. 


\section{Entry for the Table of Contents}

Insert graphic for Table of Contents here. ((Please ensure your graphic is in one of following formats))

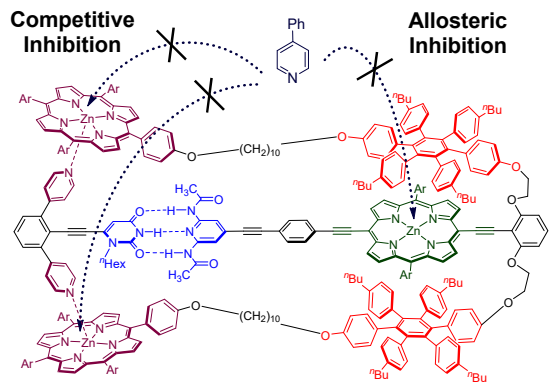

A stimulus-responsive receptor was prepared to control the ligand-binding ability of three active sites with one effector. A stable supramolecular complex of the receptor and the effector was produced via the cooperative formation of multiple hydrogen and coordination bonds. As the result, the binding of a ligand to the active sites was inhibited in a competitive and allosteric mechanism.

Institute and/or researcher Twitter usernames: ((optional)) 